\title{
Association of water-borne diseases morbidity pattern and water quality in parts of Ibadan City, Nigeria
}

\author{
O. OGUNTOKE ${ }^{1 *}$, O.J. ABODERIN ${ }^{1}$ and A.M. BANKOLE ${ }^{2}$ \\ ${ }^{1}$ Department of Environmental Management and Toxicology, University of Agriculture, PMB 2240, \\ Abeokuta, Ogun State, Nigeria \\ ${ }^{2}$ Department of Microbiology, University of Agriculture PMB 2240, Abeokuta, Ogun State, Nigeria
}

\begin{abstract}
Occurrence of diarrhoea and other water-borne diseases in cities of developing countries has been on the increase over the decades largely due to unsafe water, inadequate sanitation and poor hygiene among human population. This study examined the relationship between the spatial pattern of water-borne diseases vis-a- vis water quality in parts of Ibadan City in Nigeria. Data on 1,334 cases of various water-borne diseases was collected from eight public hospitals with catchments covering the study area. Three areas with relatively high incidence of water-borne diseases and another three areas with relatively low incidence were selected for water sampling and household survey. Water samples from rains, wells, and borehole were collected for physical and bacteriological analyses. A well structured questionnaire was administered to 350 residents of the selected areas to elicit information on water sourcing, handling and storage. Analysis of hospital records showed significant difference in the occurrence of water-borne diseases among residential areas $(P<0.05)$. Typhoid fever had the highest occurrence $(39.3 \%$ ) followed by bacillary dysentery and cholera. About $45 \%$ of water-borne diseases were reported in July to September. The majority $(77.1 \%)$ of the respondents depended on wells as major source of domestic water. Faecal coliform contamination of water samples ranged between $0.1 \times 10^{4}$ and $1.8 \times 10^{4} \mathrm{CFUml}^{-1}$. Furthermore, $18 \%$ of rain water and $23.6 \%$ of well water samples were positive to Vibrio cholerae, Salmonella typhi and Shigella dysenteriae. Potash alum application for domestic water treatment accounted for $68.6 \%$ explanation of waterborne diseases morbidity pattern in the study area $(P<0.05)$. Provision of adequate potable water remains the most important tool for preventing water-borne diseases in the study area.
\end{abstract}

Key words: urban health, water-borne diseases, water quality, Nigeria

\section{Introduction}

Water borne diseases remain a major cause of death and illness in developing countries. The global spatial distribution show that Africa and Asia account for a large percentage of these diseases, which include cholera, typhoid fever, paratyphoid, bacillary dysentery, amoebic dysentery, gastro-enteritis, and infective hepatitis (Lucas \& Gilles, 1973). Children less than five years are particularly affected adversely since they can experience as many as 10 episodes of diarrhoea in a year. Among this age group, $15-18 \%$ of mortality is attributed to diarrhoea. Nevertheless, adults are not spared the scourge of the same diseases (USAID, 2005). Generally, water-borne diseases are transmitted through the ingestion of water and food that are contaminated by faecal materials that carry infective dose of various pathogens. Some of these diseases that are acquired through the gastro-intestinal tract occur in epidemic form.
This is because they tend to affect people who share a common source of water supply over a wide area.

The prevalence of these diseases is particularly linked to the dearth of potable water in most parts of the developing countries. According to USAID (2005), diarrhoeal diseases are largely caused by unsafe water, inadequate sanitation and poor hygiene among human population. Available potablewaterin mostcities in developing countries is grossly inadequate to meet the increasing demands for water each year due to rapid population growth. Hence, the populace often results to sourcing water from questionable water points. During the dry season, which often coincides with dry public taps, urban dwellers utilize water collected from alternative sources such as boreholes, wells and streams for domestic uses. Available statistics indicate that the inhabitants of Ibadan Metropolis in Nigeria suffer mainly from diarrhoea, gastro-enteritis, malaria, measles,

*Correspondence: Dr. Oguntoke Olusegun; E-mail: timsegun67@yahoo.com 
tuberculosis, cholera and typhoid fever, in that order (Iyun, 1994). Worried by the increasing spate of water borne diseases in this part of the world, researchers have investigated the quality of water samples drawn from private wells and springs in Oregun, Lagos in Nigeria. Escherichia coli, Citrobacter freundii and Klebsilla pneumoniae were found as the most frequently isolated total coliform from water samples (Lamka et al., 1980). Staphylococcus aureus and Aeromonas hydrophila were isolated from total plate counts. Similarly, in a different study E. coli, Klebsilla aerogenes, K. edwardsii, K. rhhonsleromatic, K. stlantae, Entrobacter spp and Citrobacter spp. Were identified in water samples collected from wells in Ago-Iwoye town, Nigeria (Fagade \& Osho, 1996). All these isolated bacteria are indicators that water from these various sources are contaminated and therefore unfit for human consumption.

Drawing from the observations made by Snow (1894) to that of Swerdlow (1992), it is clear that the environmental factor "water" and the problem of water borne diseases, especially diarrhoeal diseases are linked up via two different mechanisms; through the supply of contaminated water and or lack of water for personal hygiene. Hence, this study examined the pattern of water-borne diseases in relation to water quality and other factors that could assist in unravelling the apparent intractable nature of these diseases in most cities in Nigeria.

\section{Materials and Methods}

\section{Study area}

The study was carried out in Ibadan South-West Local Government Area ( $\left.3^{0} 47^{\prime} 18^{\prime \prime} \mathrm{E} ; 7^{0} 21^{\prime} 5^{\prime \prime} \mathrm{N}\right)$ in Nigeria. It is situated at the southern part of Oyo State. The study area had a population of 282,585 people $(139,515$ male and 143,070 female) in 2006. Ibadan is a typical third world city with a dual character (a traditional sector and a modern sector) that has implications for its internal structure and its health geography. The dual character of the city is clearly seen in the marked differences in wealth, education, acquired skills, social customs and attitudes between the inhabitants of the older (eastern half) and the newer (western half) sections of the city (Mabogunje, 1968). The older section is occupied largely by the low-income groups. Their buildings are made of mud and some are plastered with cement. These are hazardously congested with as many as 74 houses per acre and high accommodation density of 2.5-4.6 persons per habitable room coupled with poor sanitation (Ayeni, 1994).

\section{Data collection}

Both primary and secondary data were collected using multi-stage approach. The first stage involved collection of hospital data for the purpose of identifying the pattern of water-borne diseases. Secondly, household questionnaire survey was conducted to identify popular water sources, water handling and other related information. The last stage was water sampling and quality analysis.

Information on the morbidity of water borne diseases was collected from eight public hospitals and health centres with catchments covering the study area. The facilities included Oyo State hospital, (Cholera Unit, Jericho), New Adeoyo hospital, Oni Memorial children hospital, Oyo State Hospital Management Board (Moor plantation, Apata), Jericho Nursing home, Ibadan South West Local Government Health Centre (Apata), Ibadan South West Local Government Health Centre (Oke-bola), and Ibadan South West Local Government Health Centre (Oja-Oba). Data collection covered a period of six years, from 1999 to 2004. Based on the aggregation of hospital data, three residential areas that recorded high incidence of water-borne diseases (Ago-Taylor, Gbekuba and Oja-oba) and another three areas with low incidence (Idi-Ishin, Oluyole and Popoyemoja) were randomly selected as study sites for household survey and water sampling.

A well-structured questionnaire was designed to collect information on water sourcing, utilization, water handling and storage as well as ailments commonly experienced by the residents. Allocation of questionnaire was based on the population of each area; 75 residents were sampled from areas with over 5,000 people while 50 residents were selected from areas with less than 5,000 people. In all, 350 respondents were selected from 350 houses drawn from the six residential areas.

Water samples meant for both physical and chemical analysis were collected in precleaned plastic bottles while the water samples for bacteriological analysis were collected in sterile bottle with gloved hand. Replicates of water samples were collected from wells and harvested rain at three different locations (sample sites) in each residential area between April and August, 2005. The water quality 
parameters determined included total bacteria count and faecal coliform count $\left(\mathrm{CFUml}{ }^{-1}\right)$. The parameters were determined using standard method for water analysis (APHA, 1989).

\section{Data analysis}

The data obtained were analysed with the aid of frequency, percentages and t-test. Correlation test was employed to examine the relationship between water quality and water handling variables on one hand and incidence of water borne diseases on the other. Finally, regression analysis was employed to identify the variables that explain the pattern of water-borne diseases in the study area. Selection of these variables followed the method adopted by Angela et al. (2002). The statistical package for social sciences (SPSS version 12.0.1) was used for all the analysis.

\section{Ethical consideration}

Prior the data collection, a formal application accompanied by the study proposal was written to Oyo State Hospital Management Board that scrutinized it for ethical implications. Based on the approval received from the ethical committee, data collection commenced in all the hospitals mentioned above. The residents selected for this survey were those who gave verbal consent to participate after being informed about the purpose of the study.

\section{Results}

Hospital records show that typhoid fever was the most $(39.3 \%)$ commonly reported waterborne disease, followed by bacillary dysentery $(26.7 \%)$. Children $<9$ years constituted $30.7 \%$ of water-borne diseases patients. Specifically, they reported $69.4 \%$ of amoebic dysentery and $48.3 \%$ of bacillary dysentery. Typhoid fever cases were most reported among the age group 20-29 years followed by 30-39 years. Gastroenteritis cases were commonest among age group 1019 years. In all, about $70 \%$ of water-borne diseases patients were less than 29 years (Table 1). Residential areas with relatively high cases of water-borne diseases included Oja-Oba, Gbekuba, and Ago-Taylor while low cases were reported from Oluyole, Jericho, Ring-Road, Iyaganku and Popoyemoja among others (Table 2 ). There was a significant spatial variation in the reported cases among the residential areas $(P<0.005)$. Seasonal pattern of water-borne diseases occurrence shows that about $50 \%$ of water-borne diseases were reported from July $(9.97 \%)$ to September $(20.01 \%)$.

Table 1: Profile of water borne diseases and the demographic characteristics of patients

\begin{tabular}{llllllllll}
\hline $\begin{array}{l}\text { Age } \\
\text { group } \\
\text { (years) }\end{array}$ & Cholera & $\begin{array}{l}\text { Typhoid } \\
\text { fever }\end{array}$ & $\begin{array}{l}\text { Bacillary } \\
\text { dysentery }\end{array}$ & Paratyphoid & $\begin{array}{l}\text { Amoebic } \\
\text { dysentery }\end{array}$ & Gastroenteritis & $\begin{array}{l}\text { Infective } \\
\text { hepatitis }\end{array}$ & Total & $\%$ \\
\hline$<5$ & 0 & 48 & 98 & 0 & 99 & 3 & 0 & 248 & 18.6 \\
$5-9$ & 8 & 53 & 74 & 5 & 19 & 2 & 0 & 161 & 12.1 \\
$10-19$ & 28 & 94 & 81 & 4 & 10 & 35 & 0 & 252 & 18.9 \\
$20-29$ & 62 & 137 & 25 & 4 & 15 & 6 & 0 & 249 & 18.7 \\
$30-39$ & 34 & 123 & 52 & 6 & 16 & 4 & 1 & 236 & 17.7 \\
$40-49$ & 30 & 52 & 22 & 3 & 5 & 2 & 2 & 116 & 8.7 \\
$50-59$ & 21 & 12 & 4 & 1 & 2 & 0 & 0 & 40 & 2.9 \\
$\geq 60$ & 21 & 5 & 0 & 0 & 4 & 2 & 0 & 32 & 2.4 \\
Total & 204 & 524 & 356 & 23 & 170 & 54 & 3 & 1334 & 100 \\
\hline
\end{tabular}


From the household survey, more than $77 \%$ of residents sampled in the study area depended on wells for the supply of domestic water. Borehole ranked as the second major source of domestic water (19\%). Tap water was not available in Gbekuba and Oja-Oba during the study period. The location of water sources to houses occupied by residents showed that $39.4 \%$ collect water within their compounds. On the other hand, $30 \%$ and $58.7 \%$ of residents at Oja-Oba and Popoyemoja, respectively, sourced water from other houses within the residential area. Of the several problems encountered by residents, water sources drying up in the course of the year due to onset of dry season ranked first $(45.8 \%)$. This was followed in magnitude by long queues at water points $(24 \%)$ (Table 3$)$. The use of common cup to draw water from pots situated strategically within the house was largely practiced by residents of Oja-Oba (84\%) and Popoyemoja (81.3\%). Common method of water treatment adopted by respondents included boiling $(42.2 \%)$ and addition of chemicals (mostly potash alum). These were popularly used by Oja-oba (77.8\%), Popoyemoja (52.4\%) and Ago-Taylor (51.4\%) residents.

All rain water samples collected from the residential areas in April (early rain period) were contaminated by faecal coliform while about $70 \%$ of the samples taken in August (period of intense rain) were contaminated. On the other hand, rain samples taken in the earlier rainy season were negative to most pathogen of water-borne diseases such as Vibrio cholerae, Salmonella typhi, Salmonella paratyphi and Shigella dysenteriae. The rain water samples were generally negative to Entamoeba histolytica and rotavirus. Furthermore, most well water samples were contaminated by faecal coliform except the observed difference in their population. The samples were also positive to V. cholerae, S. typhi, $S$. paratyphi and $S$. dysenteriae but negative to $E$. histolytica and rotavirus.

Table 2: Distribution of water-borne diseases according to residential areas, 1999-2004

\begin{tabular}{lcc}
\hline Residential area & Number of cases & Percent \\
\hline Ogunpa & 45 & 3.4 \\
Gege & 18 & 1.4 \\
Agbeni & 26 & 2.0 \\
Foko & 48 & 3.6 \\
Agbokojo & 16 & 1.2 \\
Oke-Bola & 35 & 2.6 \\
Oke-Ado & 116 & 8.7 \\
Ago-Taylor & 127 & 9.5 \\
Dugbe & 24 & 1.8 \\
Gbekuba & 145 & 10.7 \\
Iyabanku & 15 & 1 \\
Isale-Osi & 18 & 1 \\
Idi-Arere & 21 & 1.4 \\
Amunigu & 30 & 1.6 \\
Ring-Road & 16 & 2.3 \\
Araromi & 20 & 1.2 \\
Odo-Ona & 49 & 1.5 \\
Popoyemoja & 12 & 3.6 \\
Idi-Kan & 24 & 0.9 \\
Idi-Ishin & 10 & 1.8 \\
Bode & 18 & 0.8 \\
Isale-Ijebu & 30 & 1.4 \\
Jericho & 14 & 2.3 \\
Oja-Oba & 300 & 22.3 \\
Apata & 59 & 4.4 \\
Molete & 57 & 4.3 \\
Challenge & 33 & 2.5 \\
Oluyole & 834 & 0.6 \\
Total & & 100 \\
\hline
\end{tabular}


The two variables that had positive correlation with the pattern of water-borne disease within theselected areas were percentage of respondents applying chemicals (mostly potash alum) to water used for domestic activities (0.83) and the population of $E$. coli in water samples (0.75). A multivariate regression analysis showed that the percentage of residents applying alum for domestic water treatment explained 68.6\% $(P<0.04)$ of the pattern of water borne diseases morbidity in the area. While explanatory variable such as percentage earning medium income and percentage of homes with less than five persons showed negative coefficient in simple linear regression model, other variables showed positive coefficient between 1.246 and 1.67. The coefficients of $E$. coli population in water samples and total bacteria count ranged between 115.59 and 214.88 .
Lawoyin, et al., 1999).

Higher occurrence of water-borne diseases among children, especially 1-9 years may be linked to high susceptibility of children to infections due to their low immunity (Hlupheka \& Hailemariam, 2001; Aw et al., 2007). Also, children within this age group are largely dependants, who have little influence on the choice of water source unlike adults who determine where water is sourced for drinking and domestic uses. The high risk of water-borne diseases during the period of heavy rains is an index of higher water pollution. Going by the finding of Lawoyin et al. (1999), cholera cases in Ibadan were more common during the rainy season. Although, most water sources will be recharged by rains, those without adequate protection especially well and stream will experience influx of run-off, which carries high

Table 3: Number (\%) respondents on the water sources, problems and water handling practices

\begin{tabular}{|c|c|c|c|c|c|c|c|}
\hline Variable & $\begin{array}{l}\text { Ago- } \\
\text { Taylor } \\
(\mathrm{N}=50)\end{array}$ & $\begin{array}{l}\text { Gbekuba } \\
(\mathrm{N}=50)\end{array}$ & $\begin{array}{l}\text { Oja-Oba } \\
(\mathrm{N}=50)\end{array}$ & $\begin{array}{l}\text { Idi-Ishin } \\
(\mathrm{N}=50)\end{array}$ & $\begin{array}{l}\text { Oluyole } \\
(\mathrm{N}=75)\end{array}$ & $\begin{array}{l}\text { Popoyemoja } \\
(\mathrm{N}=75)\end{array}$ & $\begin{array}{l}\text { Total } \\
(\mathbf{N}=350)\end{array}$ \\
\hline \multicolumn{8}{|l|}{ Source of water } \\
\hline Well & $43(86)$ & $42(84)$ & $49(98)$ & $21(42)$ & $41(55)$ & $74(99)$ & $270(77)$ \\
\hline Borehole & $5(10)$ & $8(16)$ & $1(2)$ & $21(42)$ & $32(42)$ & - & $67(19)$ \\
\hline Tap & $2(4)$ & - & - & $3(6)$ & $2(2.7)$ & $1(1.3)$ & $8(2.3)$ \\
\hline Rain & - & - & - & $1(2)$ & - & - & $1(0.3)$ \\
\hline Stream & - & - & - & $4(8)$ & - & - & $4(1.1)$ \\
\hline \multicolumn{8}{|l|}{ Problems encountered } \\
\hline${ }^{*}$ Long distance & $6(8.6 \%)$ & $10(14)$ & $21(22)$ & $11(20)$ & $14(21)$ & $32(22)$ & $94(18.5)$ \\
\hline${ }^{*}$ Long queue & $14(20 \%)$ & $14(19)$ & $24(25)$ & $10(18)$ & $12(18)$ & $48(33)$ & $122(24)$ \\
\hline *Source drying up & $37(53 \%)$ & $36(49)$ & $33(34)$ & $23(41)$ & $39(58)$ & $65(44)$ & $233(45.8)$ \\
\hline${ }^{*}$ Dirty water & $13(18.5 \%)$ & $13(17.8)$ & $18(18.7)$ & $12(21)$ & $2(3)$ & $2(1.3)$ & $60(11.7)$ \\
\hline \multicolumn{8}{|c|}{ Water handling and treatment } \\
\hline Use of common cup & $31(62 \%)$ & - & - & - & - & - & $211(60)$ \\
\hline${ }^{*}$ Distillation & $1(2.7 \%)$ & - & - & - & - & - & $3(1.5)$ \\
\hline *Boiling & $16(43 \%)$ & - & - & - & - & - & $86(42.2)$ \\
\hline${ }^{*}$ Adding chemical & $19(51 \%)$ & - & - & - & - & - & $85(42)$ \\
\hline${ }^{*}$ Filtration & $1(2.7 \%)$ & - & - & - & - & - & $30(14.6)$ \\
\hline
\end{tabular}

* Variables with multiple responses $(\%)$ calculated based on valid cases

\section{Discussion}

High prevalence of typhoid fever in the study area may indicate the prevalence of its infective agent (S. typhi) more than the infective agents of other water-borne diseases. On the other hand, the low percentage of residents that suffered cholera episodes may reflect the impact of intervention programmes for cholera eradication against the back drop of the previous epidemics in Ibadan City (Adesina, 1990; Iyun, 1984b; load of impurities including pathogens (Fedkiw, 1991). Spatial variation in water-borne diseases' morbidity agrees with the spatial analysis of cholera cases in Ibadan City (Lawoyin et al., 1999) which depicted low income and traditional areas as high risk zones.

The overwhelming dependence of residents on private wells showed the gross inadequacy of public water supply (Iyun, 1994; Braide, 1991). Hence, domestic water is often sourced from questionable alternative sources 
especially by those who cannot afford to sink wells. Rain is quite seasonal and often polluted by anthropogenic activities in cities that release gaseous pollutants into the atmosphere, just as unprotected well can be polluted by run-off (Enger \& Smith, 2003).

Very few respondents considered the quality of water sourced at the various locations a serious problem. At Oluyole and Popoyemoja for instance, few residents considered presence of impurities in water sourced for domestic uses as a problem. Problems commonly identified by the residents are more related to the hardship encountered in sourcing water (Alagiah, 1981). Fetching water from any available well within the residential quarter implies that residents lack control over the management and hygiene of such wells. In addition, frustration because of the distance and uncertainty surrounding access make residents from low income areas to resort to water sources that are often unprotected and are hence polluted (Alagiah, 1981). Lack of protection and control over management of water sources are indications of contamination risks (WHO, 1997). Moreover, it is noteworthy that the popular water treatment methods adopted by the residents are not effective enough to eliminate several microbial contaminants (Enger \& Smith, 2003).

The contamination of the two popular sources of domestic water indicates that most residents are at-risk of water-borne diseases. The water quality result agrees with the hospital data that show a preponderance of waterborne diseases in the study area. The fact that the population of $E$. coli associate with the pattern of water borne disease in the area is aetiological, since presence of E. coli is a good indicator of excreta contamination of water bodies and also, the presence of pathogens of other water-borne diseases (Winblad, 1990; Last, 1998). In addition, positive correlation between percentage of residents that apply chemicals (mostly potash alum) and the pattern of water-borne diseases is to some extent that most residents, who add potash alum to their water, do so when visible impurities are observed. Application of potash alum as a method of water treatment is grossly inadequate as it simply coagulates sediments and aggregates bacterial contaminants and other pathogens. Proper disinfection is required before bacterial contaminants and other pathogens can be eliminated from domestic water, thereby making it safe for human consumption.

Inadequate public water supply informed the reliance of a great percentage of urban residents on private wells and rain (rainy season) for domestic water supply. These sources are polluted to a large extent by pathogen, apart from visible impurities, which are responsible for the occurrence of water-borne diseases in all residential areas in this study.

In conclusion, the findings of this study points to the fact that water sourced from rains and wells for domestic uses in different parts of the study area are not fit for drinking. Moreover, the application of potash alum for domestic water treatment especially, when visible contaminants are observed is quite inadequate as a method of treatment for water that has high coliform and bacteria load. It is therefore recommended, that potable water provision and water sanitation projects should be adopted as a veritable intervention option to solving health problems arising from water contamination rather than increased investment in drugs and building more hospitals. Again, effective and sustainable water treatment methods such as boiling, filtering, hygienic storing and handling, which can be managed at the household level, should be disseminated to households. On the other hand the ineffectiveness of alum application as a method of water treatment for drinking purposes should be discouraged. Agencies that oversee public hygiene and health issues in the urban centres should be empowered to provide and enforce management guidelines for private wells, while conducting routine assessment.

\section{Acknowledgements}

We appreciate the support of the Hospital Management Board at Ibadan, Oyo State for releasing data on reported cases of waterborne diseases for this study. Residents who participated in this study are highly appreciated for their time and cooperation. We wish to thank Dr. I.M. Adekunle her advice.

Received 1 May 2009

Revised 18 August 2009

Accepted 14 September 2009

\section{References}

Adesina, H.O. (1990) Modelling the cholera diffusion processes. In: R. Akhtar \& Y. Verhasselt (eds.) Disease Ecology and Health: Readings in Medical Geography. Rawat Pub. India. 
Alagiah, D.R. (1981) The International Drinking Water Supply and Sanitation Decade (IDWSSA). Harare, Zimbabwe.

Angela, Q., Rainer, F., Thomas, K. \& Maria, B. (2002) Geo-socio-economic factors as determinants of health: An analysis of a small area mortality rates in Germany. A paper presented at Geo-Health Conference, Victoria University of Wellington.

APHA (1989) Standard methods for the examination of water and wastewater, $17^{\text {th }}$ ed. American Public Health Association. Washington D.C.

Aw, D., Silva, A. \& Palmer, D. (2007) Immunosenescence: Emerging challenges for an ageing population. Immunology 120, 435-446.

Ayeni, M.A. (1994) The metropolitan area of Ibadan, its growth and structure. In: M.O. Filani, F.O. Akintola and C.O. Ikporukpo (eds.) Ibadan Region. Rex Charles Publishers. Ibadan.

Braide, E.I. (1991) Targeting women and children for health education in Guinea worm programme. Conference proceedings on Dracunculiasis in Nigeria. Nigerian Journal of Parasitology 99 (Suppl), 71-74.

Enger, E.D. \& Smith, B.F. (2003) Environmental Science: A Study of Interrelationships $\left(8^{\text {th }}\right.$ ed.) McGraw Hill Higher Education.

Fagade, O.E. \& Osho, A. (1996) Preliminary studies into the microbiology quality of well water samples in Ago-Iwoye using the coliform group of organisms. Journal of Pure and Applied Science 5, 51-56.

Fedkiw, J. (1991) Nitrate Occurrence in Waters. USDA, Washington D.C. As available at www.cee.vt.edu/ewr/environmental.

Hlupheka, P.C. \& Hailemariam, M. (2001) Prevalence of water-borne diseases within the health facilities in Nakuru District, Kenya. A Report Submitted to Applied Epidemiology, University of Nairobi, Kenya.

Iyun, B.F. (1984) A multivariate analysis of disease pattern in Ibadan City. Nigerian Journal of Economic and Social Studies 26, 25-39.

Iyun, B.F. (1994) Health problems in Ibadan Region. In: M.O. Filani, F.O. Akintola and C.O. Ikporukpo (eds.) Ibadan Region. Rex Charles Publishers. Ibadan 256-261.

Lamka, K.G., Lechevallier, M.W. \& Seidler, R.J. (1980) Bacteria contamination of drinking water supplies in a modern rural neighbourhood. Journal of Applied and Environmental Microbiology 39, 734738.

Last, M.J. (1998) Public Health and Human Ecology $2^{\text {nd }}$ ed. Appleton and Lange, U.S.A.

Lawoyin, T.O., Ogunbodede, N.A., Olumide, E.A. \& Onadeko, M.O. (1999) Outbreak of cholera in Ibadan, Nigeria. European Journal of Epidemiology 15, 367-370.

Lucas, A.C. \& Gilles, H.M. (1973) A Short Textbook of Preventive Medicine for the Tropics. Hodder and Stoughton, London. Sydney. Auckland. Toronto.

Mabogunje, A.L. (1968) Urbanization in Nigeria. University of London Press, London. 12-15.

Snow, N. D. (1894) The pathology and mode of communication of Cholera. London Medical Gazette 9, 745-753.

Swerdlow, D.S. (1992) Water-borne transmission of epidemic cholera in Trujilo, Peru: lessons for a continent at risk. Lancet 340, 28-33.

USAID (2005) USAID Health: Environmental Health, Overview. Available at www. usaid.gov/ oue_work/goal_health/eh.

Winblad, U. (1990) Excreta disposal and the rural poor. In: E. Norberg \& D. Finer (eds.). Society, Environment and Health in Low Income Countries. IHCAR.

WHO (1997) Guidelines for Drinking Water Quality $\left(2^{\text {nd }}\right.$ Ed.) Vol. 3: Surveillance and Control of Community Supplies. World Health Organization Library Cataloguing in Publication Data. 